\title{
"The role of university faculty motivation in human resources development and university competitiveness growth"
}

\begin{tabular}{|c|c|}
\hline AUTHORS & $\begin{array}{l}\text { Gulzhakan Mynzhanova (D https://orcid.org/0000-0002-0322-3619 } \\
\text { R http://www.researcherid.com/rid/H-9698-2018 } \\
\text { Nurlan Sailaubekov (D https://orcid.org/0000-0002-5004-746X } \\
\text { Dana Kunanbayeva }\end{array}$ \\
\hline ARTICLE INFO & $\begin{array}{l}\text { Gulzhakan Mynzhanova, Nurlan Sailaubekov and Dana Kunanbayeva (2018). } \\
\text { The role of university faculty motivation in human resources development and } \\
\text { university competitiveness growth. Problems and Perspectives in Management, } \\
\text { 16(3), 92-101. doi:10.21511/ppm.16(3).2018.08 }\end{array}$ \\
\hline DOI & http://dx.doi.org/10.21511/ppm.16(3).2018.08 \\
\hline RELEASED ON & Friday, 20 July 2018 \\
\hline RECEIVED ON & Tuesday, 24 April 2018 \\
\hline ACCEPTED ON & Monday, 11 June 2018 \\
\hline LICENSE & $\begin{array}{l}(c) E Y \\
\text { This work is licensed under a Creative Commons Attribution } 4.0 \text { International } \\
\text { License }\end{array}$ \\
\hline JOURNAL & "Problems and Perspectives in Management" \\
\hline ISSN PRINT & $1727-7051$ \\
\hline ISSN ONLINE & $1810-5467$ \\
\hline PUBLISHER & LLC "Consulting Publishing Company "Business Perspectives" \\
\hline FOUNDER & LLC "Consulting Publishing Company "Business Perspectives" \\
\hline
\end{tabular}

NUMBER OF REFERENCES

15
NUMBER OF FIGURES

1

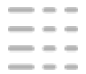

NUMBER OF TABLES

10

(C) The author(s) 2022. This publication is an open access article. 


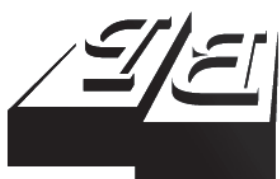

BUSINESS PERSPECTIVES

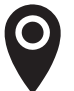

LLC "CPC "Business Perspectives" Hryhorii Skovoroda lane, 10, Sumy, 40022, Ukraine

www.businessperspectives.org

Received on: $24^{\text {th }}$ of April, 2018 Accepted on: $11^{\text {th }}$ of June, 2018

(C) Gulzhakan Mynzhanova, Nurlan Sailaubekov, Dana Kunanbayeva, 2018

Gulzhakan Mynzhanova, Ph.D. Senior Lecturer, Ph.D. Student, Faculty of Economics and Law, Kazakh Ablaikhan University of International Relations and World Languages, Kazakhstan.

Nurlan Sailaubekov, Doctor of Economic Sciences, Kazakh Ablaikhan University of International Relations and World Languages, Kazakhstan.

Dana Kunanbayeva, Ph.D. in Economic Sciences, Kazakh Ablaikhan University of International Relations and World Languages, Kazakhstan.

\section{(ㄷ)(i)}

This is an Open Access article, distributed under the terms of the Creative Commons Attribution 4.0 International license, which permits unrestricted re-use, distribution, and reproduction in any medium provided the original work is properly cited.
Gulzhakan Mynzhanova (Kazakhstan), Nurlan Sailaubekov (Kazakhstan),

Dana Kunanbayeva (Kazakhstan)

\section{THE ROLE OF UNIVERSITY FACULTY MOTIVATION IN HUMAN RESOURCES DEVELOPMENT AND UNIVERSITY COMPETITIVENESS GROWTH}

\begin{abstract}
The article aims to reveal the university rating by its faculty motivation, which has an impact on human resources development in higher education sector and raises the university competiveness level. To achieve the given goal, the researchers have developed a model for evaluating the university rating on faculty work motivation by assessing implementation of motivational factors in the university, their weight for determining its rating in comparison with the threshold value.

The article examines blocks of motivational factors, such as material-monetary, material-non-monetary and non-material. The authors believe that systemic and timely use of these blocks of motivational factors by the university may increase the lecturers' professional skills level, quality of the educational program and the academic process itself and contribute to the growth of university competitiveness.

During the research, the lecturers were surveyed by using a structured questionnaire, and a model for assessing the university faculty motivation level has been developed based on the research outcomes. Comparative analysis of the obtained results and the threshold value have been made so that to come up with conclusions on the university rating. The survey has revealed that the university under study has the $\mathrm{B}+-$ class rating, which demonstrates a fairly high result. There have been made recommendations to the given university on achieving the higher-class rating.
\end{abstract}

\section{Keywords human resource management, higher education, competitiveness, motivation, university, rewards}

JEL Classification M12, M50, M52

\section{INTRODUCTION}

In modern conditions, one of the main tasks that the university intended to solve is the competitiveness growth, because a successful solution of this problem provides a profitable position in the market of educational services in the long term. Therefore, today's universities pay special attention to improvement of the quality of educational programs. Qualified higher educational programs could increase student's enrollment, stimulate them to develop demanded skills, raise their employment level on the labor market. Such kind of programs can be offered and implemented by highly motivated professional academic staff. That's why it is very important to:

1) create valid motivational tools and mechanisms to increase professional skills of the academic staff by the universities;

2) develop indicators to evaluate competitiveness rate by implementation of motivational programs for academic staff. 
Kazakhstan universities' top management changes its attitudes in regard to the management of academic staff, as they understand that the lecturers are the key persons of the whole academic process. There are some tools of academic staff motivation used by the universities of Kazakhstan not as a system.

The system of motivational program makes it possible to increase self-interest of each academic staff in the results of their work.

According to the research results, the authors think that each university should develop and implement successful motivational program that can contribute to improve the quality of educational program and raise its competitiveness. Of course, each university may develop its own motivational program, depending on its financial and economic status.

\section{LITERATURE REVIEW}

The problem of the university competitiveness growth is studied by many domestic and foreign researchers and is interpreted by them in different ways.

According to professor Fatkhudinov (2006), university competitiveness is presented by:

1) training of specialists who can withstand competition on a specific external and internal labor market;

2) development of competitive innovations in the field where the university specializes;

3) conducting an effective reproduction policy in all areas of its activities.

The following authors Savenkova, Sovetkina (2014) use the working definition of competitiveness as the ability of the university to meet the needs of consumers of educational services in a certain set of professional knowledge, skills and abilities in conditions of direct and indirect competition. Despite the fact that the authors have different definitions of the term "competitiveness of the university", they are united in the fact that the competitiveness of the university is related to the training of personnel that can withstand competition in the labor market. The university rating determines, first of all, how the problem of ensuring the quality of graduates' training has been solved. To assess the quality of educational services, different indicators can be used in a complex, such as the training level of the university academic staff, the material and technical base of the university, the discipline and responsibility of lecturers and students, etc. Saylaubekov, Kirichok, Bagitova (2013) have developed a dynamic normative model for assessing the university's rating by analyzing the following indicators: the quality of teaching, the quality of learning and the profitability of the university.

In the educational process, the academic staff plays a key role in the training of competitive graduates. Taking into account the current development condition of the educational service market in Kazakhstan, the authors think that the successful motivational program, which is implemented by the university's top management, can contribute both to improving the quality of graduates' training process, employment level of graduates, and motivation of the university academic staff. In the authors' point of view, the system of motivational factors makes it possible to increase self-interest of each academic staff in the results of their work. The motivational program, which is developed by the university's top management, would consist of groups of factors, such as material-monetary, material-non-monetary and non-material. Active use or rejection of these factors has a positive or negative multiplier effect on increasing the competitiveness of the university. So, in the opinion of Mustak A. Said and Imrab Schaen (2013), an interested, motivated teacher plays a significant role in the effective functioning of the educational institution. The position of Chux Gervase Iwu et al. (2017) is that the teachers' level of motivation has a significant correlation to learner performance, it is, therefore, crucial to find ways of improving their job satisfaction. Creation of conditions for increasing the internal motivation of lecturers and improving the quality of the innovative climate 
at the university (Khachaturyan, Smailova, et al., 2017) would allow them to search for innovative teaching methods, to improve them theoretical knowledge base, to formulate and update the content of practical tasks on the discipline are taught. That helps to enrich the structural content of the discipline, which could lead to an improvement in the quality of educational programs and the whole organization of the academic process in the university. On the other hand, these actions improve the development of the professional competence of the lecturers.

The university as an organization, which is offering the educational services, sets a goal to achieve competitiveness growth through various ways; one of them is the motivation of academic staff. As stated in the Economic Dictionary (2005), motivation is the person stimulating process to work hard in order to achieve any goals, the existence of interest in such activities and the ways of its initiating and motivating.

Professor Vilyunas (2006) states that motivation is the aggregate system processes, which is responsible for motive and activity. Therefore, motivation can be considered as a factor that develops human resources of the higher education sphere, enhancing the professionalism of lectures, which have a positive impact on the quality of the services that are provided.
Thus, the purpose of this research paper is to develop a model for evaluating the university rating on faculty work motivation by assessing implementation of motivational factors in the university. Subject of the research is a competitiveness of the university.

\section{RESEARCH METHODS}

The method of survey was used and, based on the research outcomes, the model for evaluating the university rating is constructed. The aim of the model is to asses the implementation of motivational factors in the university to determine the university rating. The results of the research obtained on the basis of the constructed model were compared with the threshold value in order to come up with conclusions on the university rating on motivation of lecturers' work.

The questionnaire was structured according to the professor Rimskoya (2006), and consists of three blocks of the motivational factors, such as material-monetary, material-non-monetary and non-material factors. Regular and efficient use of these motivational factors may help the university management to develop university academic staff, improve the quality of education, academic training process and as a result raises the competitiveness of the university (Figure 1).

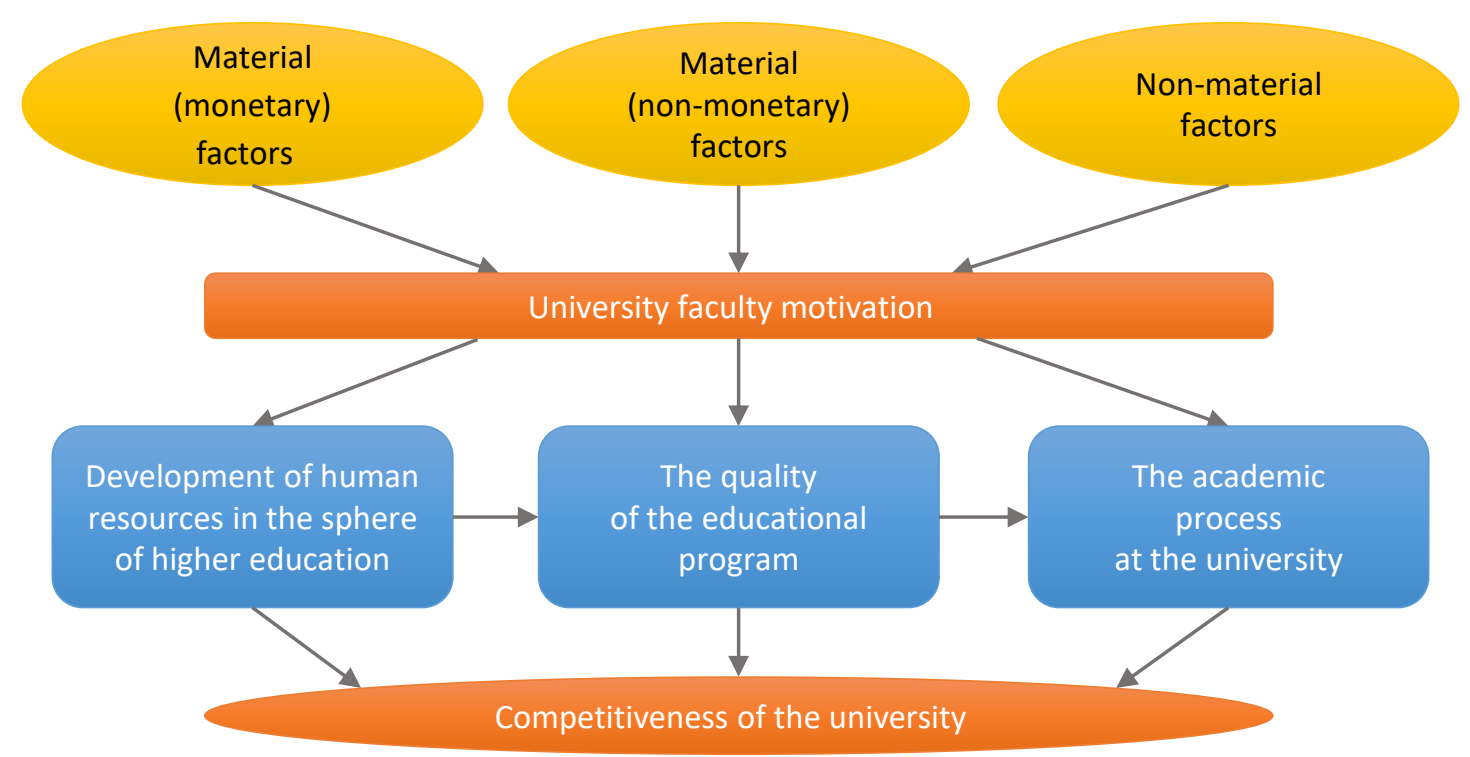

Figure 1. The impact of university faculty motivation on the university competitiveness growth 
In the questionnaire, there was used the Likert scale, which makes it possible to identify and assess respondents' opinions using the answers from 1 (completely disagree) to 5 (completely agree) (Armstrong, Kotler, 2017).

Below, the method for assessing the university rating on faculty work motivation was offered. Its aim is to assess implementation of motivational factors in the university. This method has the following steps:

1) the primary data collection and its analytical proces sing;

2) calculation of assessments for the performance of indicators for the corresponding blocks of motivational factors (material-monetary, material-non monetary and non-material);

3) calculation of estimates of the analyzed block's weight and each indicator of the corresponding block;

4) calculation of assessments for the performance of indicators for the corresponding blocks of motivational factors taking into account its weight;

5) evaluation of the block of motivational factors;

6) general assessment of the motivation of the academic staff work in the university or the university rating on the motivation of the academic staff work.

\section{RESEARCH RESULTS}

Below, each of these steps is examined in detail.

\section{Step 1. Data collection and} analytical processing of the primary information

As it was mentioned above there was used a questionnaire method to collect primary information among the lecturers of the university. The structure of the questionnaire consists of two sections. The first section covers issues reflecting the main forms of motivation for an academic staff at a higher school. This section consists of three blocks of motivational factors. The second section contains questions that characterize the general information about the respondents.

The survey was conducted among lecturers working in the field of "Economics" of the Kazakh Ablaikhan University of International Relations and World Languages (Kazakhstan, Almaty). 42 respondents participated in the survey. The age of the academic staff who participated in it is as follows: $11.8 \%$ - up to 30 years; $54 \%$ - from 31 to 45 years; $23.9 \%$ - from 46 to 64 years and $9.5 \%$ older than 65 years. The positions of the respondents are shown in Table 1.

Table 1. The position of the respondents

\begin{tabular}{l|c|c}
\hline $\begin{array}{c}\text { The position of respondents } \\
\text { who participated in the } \\
\text { survey }\end{array}$ & $\begin{array}{c}\text { The number } \\
\text { of academic } \\
\text { staff }\end{array}$ & $\%$ \\
\hline Professor & 3 & 7.1 \\
\hline Associate professor & 17 & 40.5 \\
\hline Senior lecturer & 14 & 33.35 \\
\hline Assistant professor & 8 & 19.05 \\
\hline Total & 42 & 100 \\
\hline
\end{tabular}

As shown in Table 1, a large number of respondents occupy positions of an associate professor at $40.5 \%$ and a senior lecturer at $33.35 \%$, while the share of professors and assistant professors who participated in the survey were $7.1 \%$ and 19.05 , respectively.

The work experience of the lecturers who participated in the questionnaire is presented in Table 2. Results of this indicator were as follows: $28.65 \%$ of total numbers of lecturers have worked for more than 10 years, $40.5 \%$ of respondents have worked at this university for less than 3 years, $11.8 \%$ have worked for 3 to 5 years, and $19.05 \%$ of assistant professors participating in the research have a work experience of 5-10 years (Table 2).

Table 2. Work experience of lecturers

\begin{tabular}{l|c:c}
\hline Work experience of lecturers & $\begin{array}{c}\text { Number of } \\
\text { lecturers }\end{array}$ & $\%$ \\
\hline Less than 3 years & 17 & 40.5 \\
\hline $3-5$ years & 5 & 11.8 \\
\hdashline 5-10 years & 8 & 19.05 \\
\hline More than 10 years & 12 & 28.65 \\
\hline Total & 42 & 100 \\
\hline
\end{tabular}


As was mentioned above, there were used the following groups of motivation factors, such as material-monetary, material-non-monetary, non-material factors, by following the recommendations of professor Rimskaya. She grouped these factors as the main motivational incentives for academic staff to improve the quality of educational services within the framework of the QMS (Quality Management System) (Rimskaya, 2006). Based on the model, which was proposed by her, the list of motivational factors was identified by the authors. These factors may allow us to evaluate the activity of the university from the point of view of using motivational incentives that influence the development of human resources and raise its competitiveness on the educational market.

These motivation factors are grouped into the following three blocks: the first block is the material- monetary factors (MMF); the second block - material-non-monetary factors of motivation (MnMF); the third block - non-material factors of motivation (NMF).

The information received through the questionnaire by using the Likert scale is used in Tables 3-5. At the same time, the number of respondents who rated the corresponding factor as " 1 " (completely disagree) is added to column 3 and denoted by $d_{i 1}^{k}$, the number of respondents who rated the corresponding factor as "2" (rather disagree) is written in column 4 and denoted by $d_{i 2}^{k}$, the number of respondents who chose the value of " 3 " (rather agree) is entered in column 5 and denoted by $d_{i 3}^{k}$, the number of respondents with a value of "4" (agree) is added to column 6 and denoted by $d_{i 4}^{k}$, the number of respondents who rated the corresponding factor with a value of " 5 " (completely agree) is added to column 7 and denoted by $d_{i 5}^{k}$. Hereinafter, $i$ is the number of the factor of the $k$-th block of motivational factors, where $k=1,2,3$.

\section{Step 2. Assessment of the university implementation of motivational incentives by each of the motivational factor blocks}

This assessment of indicator $D_{i}^{k}$ for $i$ factor from the $k$ block of motivational factors is calculated according to the following formula:

$$
D_{i}^{k}=\frac{d_{i 3}^{k}+d_{i 4}^{k}+d_{i 5}^{k}}{\sum_{j=1}^{5} d_{i j}^{k}}
$$

The maximum value for this assessment is determined within the framework of $0 \leq D_{i}^{k} \leq 1$. It will be assumed that the threshold value is 0.51 , i.e. most respondents (more than $50 \%$ agree with this factor). The obtained estimates are entered in column 9 in Tables 3-5.

Table 3. Calculation of assessments on the implementation of the block "material-monetary factors" (MMF)

\begin{tabular}{|c|c|c|c|c|c|c|c|c|}
\hline \multirow[b]{2}{*}{ No } & \multirow[b]{2}{*}{ Factors } & \multicolumn{5}{|c|}{ The number of respondents who were } & \multirow{2}{*}{$\begin{array}{l}\text { Total number } \\
\text { of respondents }\end{array}$} & \multirow{2}{*}{$\begin{array}{l}\text { Assessment } \\
\text { results } D_{i}^{1}\end{array}$} \\
\hline & & Completely disagree & $\begin{array}{c}\text { Rather } \\
\text { disagree }\end{array}$ & $\begin{array}{c}\text { Rather } \\
\text { agree }\end{array}$ & Agree & $\begin{array}{c}\text { Completely } \\
\text { agree }\end{array}$ & & \\
\hline 1 & MMF 1 & 2 & 3 & 8 & 5 & 24 & 42 & 0.88 \\
\hline 2 & MMF 2 & 4 & 5 & 15 & 8 & 10 & 42 & 0.785 \\
\hline 3 & MMF 3 & - & - & - & - & 42 & 42 & 1 \\
\hline 4 & MMF 4 & 4 & 5 & 11 & 12 & 10 & 42 & 0.785 \\
\hline 5 & MMF 5 & 3 & 3 & 9 & 5 & 22 & 42 & 0.857 \\
\hline 6 & MMF 6 & 4 & 6 & 17 & 4 & 9 & 40 & 0.75 \\
\hline 7 & MMF 7 & 5 & 7 & 7 & 5 & 16 & 40 & 0 \\
\hline 8 & MMF 8 & 10 & 4 & 8 & 3 & 17 & 42 & 0 \\
\hline
\end{tabular}

Note: MMF 1 - I have additional payment for practical skills and knowledge used in my work (foreign languages, new information technologies); MMF 2 - My salary satisfies me; MMF 3 - There is timely payment of my salary; MMF 4 - There is the effective bonus system at the university; MMF 5 - Monetary rewards affect my productivity; MMF 6 - I have a respectable salary; MMF 7 - I have a bonus for the following types of work (publication of manuals with the stamp of the methodology committee, monographs, and textbooks); MMF 8 - I have payments for the publications in scientific research journals, including foreign ones by the university; $D_{i}$ - the assessment results of the implementation of motivation factors of the academic staff work on the 1st block. 
Table 4. Calculation of assessments on the implementation of the block "material-non-monetary factors" (MnMF)

\begin{tabular}{|c|c|c|c|c|c|c|c|c|}
\hline \multirow[b]{2}{*}{ No } & \multirow[b]{2}{*}{ Factors } & \multicolumn{5}{|c|}{ The number of respondents who were } & \multirow{2}{*}{$\begin{array}{c}\text { Total number of } \\
\text { respondents }\end{array}$} & \multirow{2}{*}{$\begin{array}{l}\text { Assessment } \\
\text { results } D_{i}^{2}\end{array}$} \\
\hline & & $\begin{array}{c}\text { Completely } \\
\text { disagree }\end{array}$ & $\begin{array}{c}\text { Rather } \\
\text { disagree }\end{array}$ & $\begin{array}{c}\text { Rather } \\
\text { agree }\end{array}$ & Agree & $\begin{array}{c}\text { Completely } \\
\text { agree }\end{array}$ & & \\
\hline 1 & $\mathrm{MnMF} 1$ & 9 & 2 & 6 & 11 & 14 & 42 & 0.74 \\
\hline 2 & MnMF 2 & 5 & 9 & 9 & 9 & 10 & 42 & 0.666 \\
\hline 3 & MnMF 3 & 10 & 10 & 6 & 3 & 13 & 42 & 0.523 \\
\hline 4 & $\mathrm{MnMF} 4$ & 8 & 6 & 4 & 5 & 19 & 42 & 0.666 \\
\hline 5 & MnMF 5 & 2 & 1 & 7 & 9 & 23 & 42 & 0.928 \\
\hline 6 & MnMF 6 & 1 & & 6 & 12 & 23 & 42 & 0.976 \\
\hline 7 & $\mathrm{MnMF} 7$ & 10 & 7 & 3 & 4 & 18 & 42 & 0.595 \\
\hline 8 & MnMF 8 & 13 & 5 & 3 & 5 & 16 & 42 & 0.571 \\
\hline 9 & MnMF 9 & 8 & 6 & 7 & 3 & 18 & 42 & 0.666 \\
\hline
\end{tabular}

Note: MnMF 1 - I have a workplace or a personal space for work at the university; MnMF 2 - I am satisfied with the working conditions in my organization; MnMF 3 - I have the possibility to use organization transport to perform the tasks given to me; MnMF 4 - I have the opportunity to earn income from additional work (part-time work); MnMF 5 - I have the possibility of free access to library and electronic sources of information for scientific research work; MnMF 6 - I have the possibility of free access to library and electronic sources of information to prepare for classes, conduct educational work; MnMF 7 - I have the possibility of using the social facilities of the university (corporate housing, kindergarten, sports complex, recreation center); MnMF 8 - I have a social package (insurance, health examination, free meals, and transportation costs to workplace); MnMF 9 - There is a social care of top management about employees: free education (or partial payment) for children of lecturers in the university; $D_{i}^{2}$ - the assessment results of the implementation of motivation factors of the academic staff work on the $2^{\text {nd }}$ block.

Table 5. Calculation of assessment on the implementation of the block "non-material factors" (NMF)

\begin{tabular}{|c|c|c|c|c|c|c|c|c|}
\hline \multirow[b]{2}{*}{ No } & \multirow[b]{2}{*}{ Factors } & \multicolumn{5}{|c|}{ The number of respondents who were } & \multirow[b]{2}{*}{$\begin{array}{c}\text { Total number of } \\
\text { respondents }\end{array}$} & \multirow[b]{2}{*}{$\begin{array}{l}\text { Assessmen } \\
\text { results } D_{i}^{3}\end{array}$} \\
\hline & & $\begin{array}{c}\text { Completely } \\
\text { disagree }\end{array}$ & $\begin{array}{c}\text { Rather } \\
\text { disagree }\end{array}$ & $\begin{array}{l}\text { Rather } \\
\text { agree }\end{array}$ & Agree & $\begin{array}{c}\text { Completely } \\
\text { agree }\end{array}$ & & \\
\hline 1 & NMF 1 & 1 & 2 & 9 & 7 & 23 & 42 & 0.93 \\
\hline 2 & NMF 2 & 4 & 4 & 8 & 10 & 16 & 42 & 0.81 \\
\hline 3 & NMF 3 & 2 & & 4 & 14 & 22 & 42 & 0.95 \\
\hline 4 & NMF 4 & 2 & 2 & 3 & 8 & 27 & 42 & 0.90 \\
\hline 5 & NMF 5 & 5 & 6 & 6 & 8 & 17 & 42 & 0.85 \\
\hline 6 & NMF 6 & 3 & 5 & 10 & 7 & 17 & 42 & 0.81 \\
\hline 7 & NMF 7 & 3 & 7 & 7 & 3 & 22 & 42 & 0.76 \\
\hline 8 & NMF 8 & 4 & 3 & 7 & 7 & 21 & 42 & 0.83 \\
\hline 9 & NMF 9 & 1 & 1 & 8 & 8 & 24 & 42 & 0.95 \\
\hline
\end{tabular}

Note: NMF 1 - I have the possibility to participate in the implementation of the development programs of the university, faculty, specialty; NMF 2 - Top management is available to me to solve working issues; NMF 3 - The university where I work has a high rating; NMF 4 - The university has financial stability; NMF 5 - I have possibility to study abroad, have a foreign travel; NMF 6 - I have to attend upgrade training course; NMF 7 - There is an opportunity for career growth at my university; NMF 8 - There is gratitude from the administration; NMF 9 - I am satisfied with the moral climate that has been made in the my work environment; $D_{i}^{3}$ - the assessment results of the fulfillment of motivation factors of the academic staff on the 3rd block.

Step 3. Assessment of the analyzed block weight and each indicator of corresponding block

To assess the weight of each block, the method of expert evaluations is applied (Sailaubekov, 2009), which allows based on the preferences of the interested party, to rank the importance of blocks of factors motivating the work of university lecturers.

Within the framework of the expert evaluation survey, there were participated experts work- ing in the field of education for more than 10 years. They are the deans, the head of the personnel department, the head of the educational process department, and others. Experts were offered to consider the above-mentioned blocks of factors motivating the work of lecturers to rank the importance of these blocks. In accordance with the method of expert estimation, each of the experts had to propose their own rating preference of the blocks motivating the work of lecturers. The results of the expert analysis are as follows: 


$$
B_{1} \succ B_{2} \succ B_{3} \text {, }
$$

where $B_{1}$ - material-monetary block of motivation factors, $B_{2}$ - material-non-monetary block of motivation factors, $B_{3}$ - non-material block of motivation factors, $\succ-$ sign of preference.

Based on preferences (2), a matrix of pair comparisons is constructed for academic staff work motivation blocks (Table 6). In this case, if one block of factors is preferable to the other, then, in one of the corresponding cell of columns 2-4 of the matrix of pair comparisons is written 1 , otherwise zero. Thus, the cells of the matrix of pair comparisons are filled according to the following formula:

$$
m_{k j}=\left\{\begin{array}{l}
1, \text { if } B_{k}>B_{j} \\
0, \text { if } B_{k}>B_{j}
\end{array}\right\},
$$

where $k$ - number of line (block), $j$ - column number.

Then, the values of the comparisons are summarized by the line and entered in column 5 of the Table 6.

The weight of the corresponding block of factors that motivate lecturers is determined by the formula:

$$
\mu^{k}=\frac{\sum_{j=1}^{3} m_{k j}}{\sum_{k, j=1}^{3} m_{k j}} .
$$

Calculations, which are obtained by using the formula (4), are written into the corresponding cells of column 6 of Table 6 .

Table 6. The matrix of paired comparisons of motivation factors' blocks

\begin{tabular}{l:c:c:c:c|c}
\hline $\begin{array}{l}\text { The block } \\
\text { (groups) of } \\
\text { factors (B) }\end{array}$ & B1 & B2 & B3 & Sum & $\begin{array}{c}\text { Block } \\
\text { weight, } \\
\mu^{k}\end{array}$ \\
\hline B1 & 1 & 1 & 1 & 3 & 0,5 \\
\hdashline B2 & 0 & 1 & 1 & 2 & 0,3333 \\
\hdashline B3 & 0 & 0 & 1 & 1 & 0,1667 \\
\hdashline & - & - & - & 6 & 1 \\
\hline
\end{tabular}

Next, there are determined the weight of each factor by using the following formula:

$$
\mu_{i}^{k}=\frac{\mu^{k}}{\varphi^{k}}
$$

where $\mu_{i}^{k}$ the weight of the $i$ - factor of the $k-$ block, $\varphi^{k}$ - number of factors in the $k$-block.

By using the formula (5), we obtain the following weight estimates for the $i$-th factor of the $k$-th block:

$$
\begin{gathered}
\mu_{i}^{1}=\frac{0.5}{8}=0.0625 \\
\mu_{i}^{2}=\frac{0.333}{9}=0.037 \\
\mu_{i}^{3}=\frac{0.1667}{9}=0.0185
\end{gathered}
$$

When there was calculated the weight of each factor of the corresponding block, it were assumed that these factors have the same weight within the block. In the more general case, i.e. when the factors have different weights inside the unit (block), it should be applied the method of expert assessments within each unit (block).

\section{Step 4. Assessment}

of the implementation of indicators for the corresponding motivational factor blocks with its weight

The assessment of implementation of indicators for the $i$-th factor of the $k$-th block of motivational factors by taking into account its weight $\left(K_{i}^{k}\right)$ is determined by the following formula:

$$
K_{i}^{k}=\mu_{i}^{k} \cdot D_{i}^{k} .
$$

By using the formula (6), there are obtained results on the implementation of indicators for the $i$-th factor of the $k$-th block of motivational factors by taking into ac count the weight $\left(K_{i}^{k}\right)$. These results are written in column 5 of Tables 7-9. 
Table 7. Assessment of the implementation of the material-monetary block (group) factors taking into account its weight

\begin{tabular}{c:c|c:c|c}
\hline No & Factors & $\begin{array}{c}\text { Weight of } \\
\text { factors } \mu_{i}^{1}\end{array}$ & $D_{i}^{1}$ & $\begin{array}{c}\text { Evaluation of } \\
\text { factors taking } \\
\text { into account its } \\
\text { weight, } K_{i}^{i}\end{array}$ \\
\hline 1 & MMF1 & 0.0625 & 0.877 & 0.0550 \\
\hline 2 & MMF2 & 0.0625 & 0.785 & 0.0490 \\
\hline 3 & MMF3 & 0.0625 & 1 & 0.0625 \\
\hline 4 & MMF4 & 0.0625 & 0.785 & 0.0490 \\
\hline 5 & MMF5 & 0.0625 & 0.857 & 0.0468 \\
\hline 6 & MMF6 & 0.0625 & 0.75 & 0.0833 \\
\hline 7 & MMF7 & 0.0625 & 0 & 0 \\
\hdashline 8 & MMF8 & 0.0625 & 0 & 0 \\
\hline 9 & Total results & & & 0 \\
\hline & of the block 1 & & 0.346 \\
\hline
\end{tabular}

Table 8. Assessment of the implementation of the material-non-monetary block (MnMF) factors taking into account its weight

\begin{tabular}{|c|c|c|c|c|}
\hline No & Factors & $\begin{array}{l}\text { Weight of } \\
\text { factors } \mu_{i}^{2}\end{array}$ & $D_{i}^{2}$ & $\begin{array}{c}\text { Evaluation of } \\
\text { factors taking } \\
\text { into account its } \\
\text { weight, } K_{i}^{2}\end{array}$ \\
\hline 1 & MnMF1 & 0.037 & 0.74 & 0.0273 \\
\hline 2 & MnMF 2 & 0.037 & 0.666 & $0 ., 0246$ \\
\hline 3 & MnMF 3 & 0.037 & 0.523 & 0.0194 \\
\hline 4 & MnMF 4 & 0.037 & 0.666 & 0.0246 \\
\hline 5 & MnMF 5 & 0.037 & 0.928 & 0.0343 \\
\hline 6 & MnMF 6 & 0.037 & 0.976 & 0.0361 \\
\hline 7 & MnMF 7 & 0.037 & 0.595 & 0.0220 \\
\hline 8 & MnMF 8 & 0.037 & 0.571 & 0.0211 \\
\hline 9 & \multicolumn{3}{|c|}{$\begin{array}{c}\text { MnMF } 9 \\
0.037 \\
0.666\end{array}$} & 0.0246 \\
\hline 10 & $\begin{array}{l}\text { Total results } \\
\text { of the block } 2\end{array}$ & & & 0.2344 \\
\hline
\end{tabular}

Table 9. Assessment of the implementation of the non-material block (NMB) factors taking into account its weight

\begin{tabular}{c|c|c|c|c}
\hline$N^{\circ}$ & Factors & $\begin{array}{c}\text { Weight of } \\
\text { factors } \mu_{i}^{3}\end{array}$ & $D_{i}^{3}$ & $\begin{array}{c}\text { Evaluation of } \\
\text { factors taking } \\
\text { into account } \\
\text { its weight, } \\
K^{3}\end{array}$ \\
\hline 1 & NMF 1 & 0.018 & 0.93 & 0.0171 \\
\hline 2 & NMF 2 & 0.018 & 0.81 & 0.0149 \\
\hdashline 3 & NMF 3 & 0.018 & 0.95 & 0.0176 \\
\hdashline 4 & NMF 4 & 0.018 & 0.90 & 0.0167 \\
\hdashline 5 & NMF 5 & 0.018 & 0.85 & 0.0157 \\
\hdashline 6 & NMF 6 & 0.018 & 0.81 & 0.0149 \\
\hline 7 & NMF 7 & 0.018 & 0.76 & 0.0141 \\
\hline 8 & NMF 8 & 0.018 & 0.83 & 0.0154 \\
\hline 9 & NMF 9 & 0.018 & 0.95 & 0.0176 \\
\hdashline 10 & Total results of the block 3 & 0.1445 \\
\hline
\end{tabular}

\section{Step 5. Total assessment} of implementation of motivational factor blocks indicators

Assessment of the implementation of motivational factor blocks indicators $\left(K_{i}^{k}\right)$ is determined by using the following formula:

$$
K_{i}^{k}=\sum_{i=1}^{\varphi^{k}} K_{i}^{k}
$$

According to the formula, the results of the assessment are as follows:

$$
K^{1}=0.346 \quad K^{2}=0.2344 \quad K^{3}=0.1445
$$

These results are written in Tables 7-9, column 5, and the rows 9.10.10, correspondingly.

\section{Step 6. Total assessment}

\section{of the academic staff work motivation (university rating based on the academic staff motivation)}

The overall assessment of the university faculty work motivation or the rating of the university on the motivation of the academic staff work is calculated by the following formula:

$$
R=K^{1}+K^{2}+K^{3}
$$

The formula (9) determines the rating assessment of the academic staff motivation. It takes into account the importance of the group of indicators by introducing weight indices to differentiate the assessment in accordance with the threshold values of evaluation. The threshold value is defined as 0.51 points.

The result of rating estimation on the academic staff work motivation of the studied University is in the period from 0 to 1 .

The formula (9) and calculations (8) are used to identify the rating of the given university on the academic staff work motivation, which is equal to:

$$
R=0.346+0.2344+0.1445=0.7249 .
$$

According to the research outcomes, the studied university has a grade $B+$ that belongs to the inter- 
Table 10. Classification of the university rating on academic staff work motivation

\begin{tabular}{|c|c|c|c|c|}
\hline & Grade & Position & Rating results & The meaning of rating value \\
\hline \multirow{3}{*}{ A } & $A+$ & \multirow{3}{*}{ High } & \multirow{3}{*}{$0.81-1.0$} & $0.95-1.0$ \\
\hline & A & & & $0.91-0.95$ \\
\hline & A- & & & $0.81-0.9$ \\
\hline \multirow{3}{*}{ B } & $\mathrm{B}+$ & \multirow{3}{*}{ Medium } & \multirow{3}{*}{$0.51-0.80$} & $0.71-0.80$ \\
\hline & B & & & $0.61-0.70$ \\
\hline & $B-$ & & & $0.51-0.60$ \\
\hline C & $\mathrm{C}$ & Low & $0-0.50$ & $0-0.50$ \\
\hline
\end{tabular}

vals of 0.71-0.80 in Table 8. According to the classification, this is a fairly high result.

There are proposed the following classification of rating assessment of the academic staff motivation, which divides the period from 0 to 1 into a number of intervals (Table 10).

The main characteristics of the proposed method: "Classification of the university rating on academic staff work motivation" are as follows:
- the proposed method is based on an integrated approach in assessing the motivation of lecturers;

- the rating assessment is based on survey/questionnaire data;

- the rating score is comparative;

the flexible computational algorithm is used to obtain the rating evaluation of academic staffs 'work motivation.

\section{CONCLUSION}

In the given research paper, the complex method of estimation of academic staff work motivation (assessment of the university rating on academic staff work motivation) is developed. This method is tested on the basis of Kazakh Ablai khan University of international relations and world languages. There was assessed the motivational factors implementation in the university by taking into account their weight. This algorithm includes the following steps such as primary data collection and its analytical processing, calculation of assessments for the performance of indicators for the corresponding blocks of motivational factors (material-monetary, material-non monetary and non-monetary), calculation of estimates of the analysed block's weight and each indicator of the corresponding block, calculation of assessments for the performance of indicators for the corresponding blocks of motivational factors taking into account its weight, evaluation of the block of motivational factors, general assessment of the motivation of the academic staff work or the university rating on the motivation of the academic staff work.

Comparative analysis of the obtained results and the threshold value have been made so that to come up with conclusions on the university rating. This model may be used to determine the current rating of the university on the faculty work motivation, which has impact on the human resource development and the university competitiveness growth. The survey has revealed that the university under study has the $\mathrm{B}+-$ class rating $(0.7249)$, which demonstrates a fairly high result according to Table 10 . There have been made recommendations to the given university on achieving the higher class rating.

\section{RECOMMENDATION}

On the basis of the conducted research, there were proposed recommendations aimed at the development of human resources and raise the rating of the University on the motivation of the academic staff, among which the following of them should be noted: 
- taking into consideration the situation with the shortage of textbooks, manuals and cases, especially in Kazakh language, the higher education institution should provide incentives for academic staff to increase the publication of them;

- in order to stimulate publications in foreign scientific journals, including cited publications, higher education institution should introduce options to encourage academic staff for active research activities.

\section{REFERENCES}

1. Alam, T. A. \& Farid, S. (2011). Factors Affecting Teachers Motivation. International Journal of Business and Social sciences, 2(1) January 2011.

2. Armstrong, G., Kotler, Ph. (2017). Marketing: An Introduction (12th ed.).

3. Chux Gervase Iwu, Ikechukwu O. Ezeuduji, Ita Chimezie Iwu, Kenechukwu Ikebuaku, \& Robertson K. Tengeh (2017). Job motivation and management implications: a case of teachers in Nigeria. Problems and Perspectives in Management, 15(2-1), 277287. https://doi.org/10.21511/ ppm.15(2-1).2017.11

4. Economic dictionary (2005). Retrieved from http://www.endic.ru/ anticrisis/Motivacija-270.html

5. Fatkhutdinov, R. A. (2006). Management of competitiveness of higher education institution. Higher education in Russia, 9, 3738 (in Russian).

6. Justine Mercer, Bernard Barker, \& Richard Bird (2010). Human Resource Management in Education (1st ed.). London.
7. Khachaturian, M. V., Smailova, Zh. P. et al. (2017). Technologies of effective management: peculiarities of innovation implementation in the management system. Almaty (in Russian).

8. Mushtaq A. Sajid, Imrab Shaheen (2013). Factors responsible for High and Low motivational level of University Academicians. International Journal of Sciences and research. India.

9. Panzabekova, A. Zh., Tyurabayev, G. K. (2016). Foreign experience of formation of payment gateway and labour promotion in terms of innovative development. Bulletin of National academy of sciences of the Republic of Kazakhstan, 5(363), 219-226.

10. Pererva, P., Hutsan, O., Kobieliev, V. et al. (2018). Evaluating elasticity of costs for employee motivation at the industrial enterprises. Problems and Perspectives in Management, 16(1), 124132. http://dx.doi.org/10.21511/ ppm.16(1).2018.12
11. Rimskaya, O. N. (2006). Motivation of University teachers in the system of education quality management. Monograph, Tomsk (in Russian).

12. Sailaubekov, N. T. (2009). Management decisions. Theory and practice, textbook. Almaty: Publisher KBTU.

13. Savenkova, Yu. S., \& Sovetkina, A. A. (2009). Management of competitiveness of the University in modern socioeconomic conditions. Education issues, 4, 182-198. Retrieved from https://vo.hse.ru/ data/2014/02/25/1330115884

14. Saylaubekov, N. T., Kirichok, O. V., Bagitova, S. (2013). Rating of the quality of education based on the dynamic normative model. Actual problems of economy, 12(150), 492-499.

15. Vilyunas, V. K. (2006). Psychology of development of motivation. St. Petersburg: Speech. 